\title{
ANALISIS FAKTOR RISIKO YANG DAPAT DIKENDALIKAN PADA KEJADIAN PJK USIA PRODUKTIF
}

\author{
ANALYSIS OF MODIFIABLE RISK FACTORS CORONARY HEART DISEASE IN \\ PRODUCTIVE AGE
}

\author{
Desta Saesarwati, Prijono Satyabakti \\ Departemen Epidemiologi \\ Fakultas Kesehatan Masyarakat Universitas Airlangga \\ Email : destasaesarwati@gmail.com
}

\begin{abstract}
Coronary heart disease is one of cardiovascular disease dan being number one of mortality cause in world. Coronay heart disease is begun with atherosclerosis. Atherosclerosis is process of accumulation of cholesterol in wall of heart's blodd vessels that causes stenosis (obstruction). These days coronary heart disease attacked productive people. Some risk factors of coronary heart disease are smoking habit, physical inactivity, hypertension, intake of unhealthy food, and stress. The aims of this research was to analyse modifiable risk factors of coronary heart disease in productive age that consists of smoking habit, physical inactivity, and stress. This study was an analytical study that used cross sectional design conducted at cardiology clinic RSU Haji Surabaya at March-May 2016. The population in this study were all patients of cardiology clinic in RSU Haji Surabaya with 91 patients as samples. The data described that there were no significant correlation between smoking habit ( $p=$ $0,22)$, physical inactivity $(p=0,79)$, dan stress $(p=0,06)$ with the incident of coronary heart disease in productive age, and there was significant correlation between passive smoker status with correlation of coronary heart disease in productive age $(p=0,01)$. The conclusion are there were no significant correlation between smoking habit, physical inactivity, and stress with incident of coronary heart disease in productive age, and there was significant correlation between passive smoker status with incident of coronary heart disease in productive age.
\end{abstract}

Keywords: risk factors, coronary heart disease, productive age

\begin{abstract}
Abstrak: Penyakiy Jantung Koroner (PJK) adalah bentuk utama penyakit kardiovaskular dan menjadi penyebab kematian nomor satu di dunia. PJK terjadi diawali oleh proses aterosklerosis yaitu proses penumpukan kolesterol pada dinding pembuluh darah sehingga terjadi stenosis (penyumbatan). Dewasa ini PJK sudah banyak menyerang golongan usia produktif. Faktor risiko PJK diantaranya adalah kebiasaan merokok, kebiasaan olahraga, hipertensi, konsumsi makanan kurang sehat, dan stres. Tujuan dari penelitian ini adalah menganalisis faktor risiko yang dapat dikendalikan pada kejadian PJK usia produktif, yaitu terdiri dari kebiasaan merokok, kebiasaan olahraga, dan stres. Penelitian ini merupakan penelitian observasional analitik dengan desain cross sectional yang dilakukan di poli jantung RSU Haji Surabaya pada bulan Maret-Mei 2016. Populasi dalam penelitian ini merupakan pasien berusia 15-64 tahun yang memeriksakan diri poli jantung di RSU Haji Surabaya dengan 91 orang sebagai sampel. Berdasarkan hasil penelitian diketahui bahwa tidak ada hubungan yang signifikan antara kebiasaan merokok $(p=0,22)$, kebiasaan olahraga $(p=0,79)$, dan tingkat stres $(p=0,06)$ dengan kejadian PJK pada usia produktif, dan ada hubungan antara status perokok pasif dengan kejadian PJK pada usia produktif dengan $p=0,01$. Kesimpulan yang dapat diambil adalah tidak terdapat hubungan yang signifikan antara kebiasaan merokok, kebiasaan olahraga, dan tingkat stres dengan PJK pada usia produktif, dan ada hubungan antara status perokok pasif dengan kejadian PJK pada usia produktif.
\end{abstract}

Kata kunci : faktor risiko, PJK, usia produktif

\section{PENDAHULUAN}

Di dunia setiap tahunnya terjadi lebih dari 36 juta kematian akibat Penyakit Tidak Menular (PTM). Dari jumlah tersebut, seperempatnya atau lebih dari 9 juta kematian tersebut terjadi dibawah 60 tahun.
Secara global PTM penyebab kematian nomor satu setiap tahunnya adalah penyakit kardiovaskular. Menurut Bustan (2007), dari sepuluh penyebab kematian, dua diantaranya adalah penyakit jantung dan stroke. Penyakit kardiovaskular merupakan 
penyakit yang terjadi karena gangguan pada jantung dan pembuluh darah. Beberapa jenis penyakit kardiovaskular diantaranya adalah Penyakit Jantung Koroner (PJK), gagal jantung, hipertensi dan stroke (Kementrian Kesehatan RI, 2014). PJK menjadi penyebab kematian nomor satu di dunia dan menjadi masalah kesehatan yang dihadapi berbagai negara di dunia, baik negara maju atau negara berkembang. Oleh karena itu, PJK merupakan salah satu penyakit yang menjadi global burden disease. Di Amerika Serikat diperkirakan lebih dari 500.000 orang meninggal karena PJK. Sedangkan di Eropa diperkirakan 20.000-40.000 orang per satu juta jiwa menderita penyakit tersebut (Afriyanti et al., 2015). PJK merupakan penyebab kematian utama pada laki-laki berusia 35- 44 tahun, dan $40 \%$ kematian pada laki-laki usia 55-65 tahun (Setiani, 2008). Di Indonesia menurut hasil Riskesdas tahun 2013, penderita PJK meningkat seiring dengan bertambahnya usia. Prevalensi PJK berdasar diagnosis dokter sebesar $0,5 \%$ atau sebesar 883.447 orang, sedangkan berdasar diagnosis dokter/gejala sebesar 1,5\% atau sebesar 2.650 .340 orang. Perkiraan jumlah penderita PJK tertinggi diduduki Jawa Timur yaitu 1,3\% atau sekitar 375.127 orang. Diperkirakan dimasa depan $82 \%$ angka mortalitas akibat PJK terjadi di negara berkembang. Tinggi atau rendahnya derajat kesehatan masyarakat bisa dipengaruhi oleh faktor lingkungan, perilaku, dan gaya hidup, pelayanan kesehatan, dan faktor biologis. Di Indonesia kemajuan dalam bidang ekonomi merupakan salah satu faktor yang berkontribusi dalam meningkatnya prevalensi PJK yang terus meningkat.

Semakin berkembang kemajuan perekonomian Indonesia menyebabkan pola hidup masyarakat berubah sehingga dapat mempengaruhi kesehatan masyarakat. Faktor yang memiliki pengaruh besar pada kesehatan masyarakat adalah faktor lingkungan, perilaku, dan gaya hidup. Faktor perilaku yang memiliki pengaruh besar terhadap kejadian PJK adalah kebiasaan merokok, dan kebiasaan olahraga. Selain itu perubahan dan pergeseran dalam gaya hidup menyebabkan faktor risiko PJK semakin beragam. Perbedaan angka mortalitas pada berbagai negara karena PJK disebabkan oleh perbedaan pada bermacam faktor risiko utama (mayor) pada tiap negara, terutama tekanan darah tinggi, kolesterol darah, kebiasaan merokok, kurangnya aktivitas fisik, dan konsumsi makanan (Ramandika, 2012). Sebanyak $80-90 \%$ masyarakat yang meninggal karena PJK memiliki lebih dari satu faktor risiko utama karena berubahnya pola hidup masyarakat. PJK menjadi permasalahan dalam kesehatan masyarakat karena menyebabkan tingginya angka morbiditas dan angka mortalitas. Angka prevalensi PJK juga mengalami peningkatan setiap tahunnya (Herman et al., 2015).

PJK adalah gangguan yang terjadi akibat jantung kekurangan suplai darah dan nutrisi. Hal ini disebabkan karena adanya timbunan plak (trombus) dalam pembuluh darah arteri yang mengalirkan darah menuju jantung. Penumpukan plak ini biasa disebut dengan aterosklerosis. Menurut Bustan (2007) aterosklerosis dapat menyebabkan penyempitan saluran pembuluh darah menuju jantung yang mengakibatkan kurangnya asupan darah untuk otot jantung. Menurut American Health Association (AHA) bentuk PJK yang umum dikenal adalah silent ischemia, angina pectoris, unstable angina, serangan jantung (myocardial infarction atau MI), dan kematian mendadak (sudden death) (American Heart Association, 2015). Sedangkan tanda-tanda umum serangan jantung adalah nyeri dada yang menetap selama kurang lebih 10 menit, sakit yang terasa di bagian belakang tulang dada kiri, dan rasa sakit yang terasa mulai dari bagian bawah lengan atas dan dapat menjalar keatas, kebahu kiri, keleher atau rahang bawah. PJK dapat dideteksi atau diketahui melalui pemeriksaan Elektrokardiogram (EKG), treadmill (test toleransi), foto rontgen dada, pemeriksaan laboratorium, dan kateterisasi. PJK merupakan penyakit yang dapat "ditularkan" melalui suatu bentuk "penularan sosial" yang berhubungan dengan gaya hidup masyarakat. Modernisasi disusul dengan perubahan gaya hidup dapat dianggap sebagai penyebab PJK. Melihat fenomena yang ada di masyarakat saat ini, umumnya masyarakat yang berusia produktif banyak yang menikmati gaya hidup tidak sehat dalam kehidupan sehari-hari. Gaya 
hidup tidak sehat yang dimaksud diantaranya adalah memiliki kebiasaan merokok, konsumsi makanan, kurang aktifitas fisik, dan stres. Perilaku makan penduduk saat ini juga telah berubah dari konsumsi makanan tradisional ke konsumsi makanan modern, kebaratan, atau instan yang mengandung kandungan lemak, kolesterol, gula, garam, dan bahan pengawet yang tinggi. Perilaku ini banyak dialami oleh penduduk perkotaan yang banyak dijumpai gerai makanan siap saji dan pusat perbelanjaan yang terdapat banyak restoran. Makanan yang dijual pun beragam. Umumnya makanan kebaratan, dan juga makanan yang banyak mengandung lemak, kolesterol, dan bahan pengawet. Surabaya merupakan kawasan perkotaan dan terdapat banyak pusat perbelanjaan serta gerai makanan cepat saji. Oleh karena itu, banyak masyarakat Surabaya yang sering mengkonsumsi makanan tersebut, dan sebagian besar konsumen makanan cepat saji adalah penduduk berusia produktif yaitu antara umur 15-64 tahun. Penduduk berusia produktif dapat dikatakan sebagai penduduk yang masih bekerja, dan memiliki kesempatan bekerja.

Faktor risiko PJK dapat dibedakan menjadi faktor risiko yang dapat dikendalikan dan faktor risiko yang tidak dapat dikendalikan. Faktor risiko yang dapat dikendalikan yaitu faktor risiko yang dapat diubah dengan cara merubah perilaku yang berisiko. Faktor risiko PJK yang dapat dikendalikan diantaranya adalah hipertensi, obesitas, kadar kolesterol darah, konsumsi alkohol, kebiasaan olahraga, kebiasaan merokok, dan stres. Umur, genetik, dan faktor metabolisme adalah faktor risiko PJK yang tidak dapat dikendalikan.

Olahraga bisa berperan sebagai faktor pelindung atau protektif terhadap PJK. Kurang olahraga dapat menjadi faktor penting yang berkontribusi pada PJK. Dengan melakukan olahraga teratur dapat menurunkan tekanan darah sistol, menurunkan kadar kolesterol darah, kadar Low Density lipoprotein (LDL), dan meningkatkan aliran darah dari organ yang aktif ke organ yang kurang aktif serta dapat mengurangi faktor risiko PJK. Merokok juga dapat menjadi faktor yang berkontribusi pada kejadian PJK. Nikotin yang terkandung dalam rokok dapat mengakibatkan penyempitan pembuluh darah akibat adanya pengapuran sehingga akan terjadi ateriosklerosis yang merupakan gejala awal PJK. Stres dapat menyebabkan terproduksinya hormon adrenalin, dimana hormon tersebut dapat menyebabkan jantung berdetak lebih cepat dan bisa mempengaruhi metabolisme lemak sehingga yang akan banyak tersebar di dalam tubuh adalah LDL. LDL merupakan jenis kolesterol yang bersifat merugikan. Jika LDL terus menumpuk maka akan terjadi aterosklerosis. Berlawanan dengan LDL, High Density Lipoprotein (HDL) merupakan jenis kolesterol yang bersifat menguntungkan. HDL dapat mencegah timbulnya plak dalam pembuluh darah atau ateriosklerosis.

Penelitian ini bertujuan untuk menganalisis faktor risiko PJK pada usia produktif yang dapat dikendalikan meliputi kebiasaan merokok, kebiasaan olahraga, dan stres. Dengan mengetahui faktor risiko yang dapat dikendalikan diharapkan dapat meningkatkan kewaspadaan masyarakat dan tenaga kesehatan sehingga dapat mencegah kejadian PJK. Manfaat dari penelitian ini diharapkan dapat memberikan informasi pada masyarakat tentang faktor risiko PJK yang dapat dikendalikan sehingga dapat dilakukan tindakan pencegahan.

\section{METODE}

Penelitian ini dilakukan di poli jantung RSU Haji Surabaya pada bulan Maret-Mei 2016. Jenis penelitian adalah penelitian observasional analitik dengan desain cross sectional. Populasi penelitian ini adalah semua pasien poli jantung RSU Haji yang berusia 15-64 tahun pada bulan April 2016 yaitu sebesar 1.423 pasien. Besar sampel dalam penelitian ini dihitung dengan metode simple random sampling yaitu semua anggota populasi memiliki kesempatan yang sama untuk menjadi sampel. Dari hasil penghitungan besar sampel menggunakan metode simple random sampling didapatkan hasil jumlah sampel sebanyak 91 responden. Variabel dependen dalam penelitian ini adalah kejadian PJK pada usia produktif. Variabel dependen yang diteliti adalah merokok, kebiasaan olahraga, dan stres. 
Data diagnosis PJK didapatkan melalui rekam medis pasien. Sedangkan variabel merokok, kebiasaan olahraga, dan stres didapatkan melalui pengukuran/wawancara langsung menggunakan kuisioner. Untuk mengukur tingkat stres, peneliti menggunakan instrument Depression Anxiety Stress Scale 42 (DASS 42). DASS 42 terdiri dari pertanyaan untuk pengukuran depresi, kecemasan, dan stres. Pengolahan data dilakukan analisis secara univariat dan bivariat. Analisis univariat berguna untuk menggambarkan variabel dependen dan independen pada sampel dengan menggunakan tabel distribusi frekuensi. Sedangkan analisis bivariat digunakan untuk menganalisis hubungan antara merokok, kebiasaan olahraga, dan stres dengan kejadian PJK pada usia produktif dengan menggunakan analisis chi-square yang ada dalam aplikasi Epi Info.

\section{HASIL PENELITIAN}

RSU Haji Surabaya merupakan rumah sakit tipe B milik pemerintah Provinsi Jawa Timur. RSU Haji Surabaya terletak di Jalan Manyar Kertoadi Surabaya. Selain sebagai rumah sakit umum, RSU Haji Surabaya juga merupakan rumah sakit pendidikan. Di RSU Haji Surabaya terdapat pelayanan kesehatan mulai dari pelayanan rawat jalan, rawat inap, laboratorium, unit hemodialisis, kamar bersalin, kamar operasi, ICU, ICCU, dan NICU. Pelayanan rawat jalan memiliki beberapa poli yang siap untuk melayani pasien. Salah satu poli yang memiliki jumlah kunjungan tertinggi adalah poli jantung. Pasien poli jantung merupakan pasien dengan keluhan hipertensi dan penyakit kardiovaskular lainnya, serta melayani pemeriksaan EKG untuk keperluan operasi. Rata-rata pasien yang berkunjung di poli jantung setiap harinya adalah 100-150 pasien. Berdasarkan data instalasi rawat jalan RSU Haji Surabaya, jumlah kunjungan poli jantung pada bulan Januari-April 2016 mencapai 10.995 kunjungan.

Karakteristik responden berdasarkan usia, jenis kelamin, pekerjaan, dan tingkat pendidikan di poli jantung RSU Haji Surabaya dapat dilihat pada tabel 1. Tabel 1 menjelaskan bahwa karakteristik responden
Tabel 1. Karakteristik Responden Berdasarkan Usia, Jenis Kelamin, Pekerjaan, dan Tingkat Pendidikan di Poli Jantung RSU Haji Surabaya

\begin{tabular}{|c|c|c|c|}
\hline \multicolumn{2}{|c|}{ Karakteristik Responden } & \multirow{2}{*}{$\frac{n}{3}$} & \multirow{2}{*}{$\begin{array}{r}\% \\
3,3\end{array}$} \\
\hline \multirow{4}{*}{ Usia } & 30-40 tahun & & \\
\hline & 41-50 tahun & 18 & 19,8 \\
\hline & 51-60 tahun & 53 & 58,2 \\
\hline & 61-64 tahun & 17 & 18,7 \\
\hline \multirow{2}{*}{ Jenis Kelamin } & Perempuan & 54 & 59,3 \\
\hline & Laki-laki & 37 & 40,7 \\
\hline \multirow{6}{*}{ Pekerjaan } & $\begin{array}{l}\text { PNS/TNI/ } \\
\text { Polri }\end{array}$ & 11 & 12,1 \\
\hline & Swasta & 19 & 20,9 \\
\hline & Pedagang & 5 & 5,5 \\
\hline & Buruh & 5 & 5,5 \\
\hline & Pensiun & 9 & 9,9 \\
\hline & Tidak bekerja & 38 & 41,8 \\
\hline \multirow{6}{*}{ Tingkat Pendidikan } & Tidak sekolah & 2 & 2,2 \\
\hline & $\mathrm{SD}$ & 16 & 17,6 \\
\hline & SMP & 29 & 31,9 \\
\hline & SMA & 33 & 36,3 \\
\hline & D3 & 3 & 3,3 \\
\hline & Sarjana & 8 & 8,8 \\
\hline
\end{tabular}

berdasar umur terbanyak adalah kelompok umur 51-60 tahun sebanyak 58,2\%. Karakteristik responden berdasarkan jenis kelamin, pekerjaan, dan pendidikan terakhir yaitu $59,3 \%$ responden berjenis kelamin perempuan, $41,8 \%$ responden tidak bekerja, dan $36,3 \%$ responden memiliki pendidikan terakhir tingkat SMA.

Karakteristik responden mengenai kebiasaan olahraga, kebiasaan merokok, dan stres dapat dilihat pada tabel 2 . Berdasarkan hasil penelitian pada tabel 2 dapat diketahui bahwa $63,7 \%$ responden tidak memiliki kebiasaan merokok. Sebanyak $72,73 \%$ responden yang memiliki kebiasaan merokok mulai merokok pada usia $\geq 20$ tahun, 54,\% responden merokok $>10$ batang per hari, dan $72,7 \%$ responden merokok menggunakan rokok berjenis filter. Selanjutnya $68,1 \%$ responden merupakan perokok pasif. Untuk kebiasaan olahraga, $61,5 \%$ responden tidak memiliki kebiasaan olahraga. 
Tabel 2. Karakteristik Responden Berdasarkan Kebiasaan Merokok, Kebiasaan Olahraga, dan Tingkat Stres di Poli Jantung RSU Haji Surabaya

\begin{tabular}{|c|c|c|c|}
\hline \multicolumn{2}{|c|}{ KARAKTERISTIK RESPONDEN } & \multirow{2}{*}{$\begin{array}{c}\mathbf{n} \\
11\end{array}$} & \multirow{2}{*}{$\begin{array}{c}\mathbf{\%} \\
12,1\end{array}$} \\
\hline \multirow{4}{*}{ Kebiasaan Merokok } & $\mathrm{Ya}$ & & \\
\hline & Tidak & 58 & 63,7 \\
\hline & Pernah & 22 & 24,2 \\
\hline & Jumlah & 91 & 100 \\
\hline \multirow{3}{*}{ Usia Mulai Merokok } & $<20$ tahun & 3 & 27,27 \\
\hline & $\geq 20$ tahun & 8 & 72,73 \\
\hline & Jumlah & 11 & 100 \\
\hline \multirow{3}{*}{ Jumlah Rokok Yang Dihisap Perhari } & $<10$ batang & 6 & 54,5 \\
\hline & 10-20 batang & 5 & 45,5 \\
\hline & Jumlah & 11 & 100 \\
\hline \multirow{3}{*}{ Jenis Rokok Yang Digunakan } & Filter & 8 & 72,7 \\
\hline & Non filter & 3 & 27,3 \\
\hline & Jumlah & 11 & 100 \\
\hline \multirow{3}{*}{ Perokok Pasif } & Ya & 62 & 68,1 \\
\hline & Tidak & 29 & 31,9 \\
\hline & Jumlah & 91 & 100 \\
\hline \multirow{3}{*}{ Kebiasaan Olahraga } & $\mathrm{Ya}$ & 35 & 38,5 \\
\hline & Tidak & 56 & 61,5 \\
\hline & Jumlah & 91 & 100 \\
\hline \multirow{3}{*}{ Frekuensi Olahraga Per Minggu } & $<3$ kali & 25 & 71,4 \\
\hline & $\geq 3$ kali & 10 & 28,6 \\
\hline & Jumlah & 35 & 100 \\
\hline \multirow{3}{*}{ Lama Olahraga } & $\leq 30$ menit & 21 & 60 \\
\hline & $>30$ menit & 14 & 40 \\
\hline & Jumlah & 35 & 100 \\
\hline \multirow{6}{*}{ Tingkat Stres } & Normal & 21 & 23,1 \\
\hline & Ringan & 25 & 27,5 \\
\hline & Sedang & 37 & 40,7 \\
\hline & Berat & 8 & 8,8 \\
\hline & Sangat Berat & 0 & 0 \\
\hline & Jumlah & 91 & 100 \\
\hline
\end{tabular}

Untuk responden yang memiliki kebiasaan olahraga, $71,4 \%$ responden berolahraga $<3$ kali per minggu, dan $60 \%$ responden berolahraga $\leq 30$ menit. Berdasarkan hasil penelitian dapat diketahui bahwa $40,7 \%$ responden mengalami tingkat stres sedang.

Analisis bivariat hubungan faktor risiko yang dapat dikendalikan dengan kejadian PJK pada usia produktif menggunakan analisis chi-square dapat dilihat pada tabel 3.

Berdasarkan tabel 3 dapat diketahui bahwa $72,7 \%$ responden yang memiliki kebiasaan merokok menderita PJK.
Sebanyak $71 \%$ responden yang merupakan perokok pasif menderita PJK, dan 100\% responden yang menderita PJK mengalami stres berat. Variabel status perokok pasif bermakna karena $p$ value sebesar 0,01 dengan nilai Ratio Prevalens 1,58. Sedangkan variabel lain dinyatakan tidak bermakna.

\section{PEMBAHASAN}

Menurut hasil analisis bivariat faktor risiko kebiasaan merokok yang terdiri dari kebiasaan merokok, umur mulai merokok, 
Tabel 3. Analisis Hubungan Faktor Risiko Yang Dapat Dikendalikan Dengan Kejadian PJK Pada Usia Produktif

\begin{tabular}{|c|c|c|c|c|c|c|}
\hline \multirow{2}{*}{ Faktor Risiko Yang Dapat Dikendalikan } & \multicolumn{2}{|c|}{ PJK } & \multicolumn{2}{|c|}{ Tidak PJK } & \multirow[t]{2}{*}{ Total } & \multirow{2}{*}{ p value } \\
\hline & n & $\%$ & n & $\%$ & & \\
\hline \multicolumn{7}{|l|}{ Kebiasaan Merokok } \\
\hline Ya & 8 & 72,7 & 3 & 27,3 & 11 & \multirow{2}{*}{0,22} \\
\hline Tidak & 32 & 55,2 & 26 & 44,8 & 58 & \\
\hline \multicolumn{7}{|l|}{ Umur Mulai Merokok } \\
\hline$<20$ tahun & 2 & 100 & 0 & 0 & 2 & \multirow[t]{2}{*}{0,509} \\
\hline$\geq 20$ tahun & 6 & 66,7 & 3 & 33,3 & 9 & \\
\hline \multicolumn{7}{|l|}{ Jumlah Rokok Yang Dihisap Per Hari } \\
\hline$\geq 10$ batang & 3 & 60 & 2 & 40 & 5 & \multirow[t]{2}{*}{0,42} \\
\hline$<10$ batang & 5 & 83,3 & 1 & 16,7 & 6 & \\
\hline \multicolumn{7}{|l|}{ Jenis Rokok Yang Dihisap } \\
\hline Filter & 6 & 75 & 2 & 25 & 8 & \multirow[t]{2}{*}{0,66} \\
\hline Non Filter & 2 & 66,7 & 1 & 33,3 & 3 & \\
\hline \multicolumn{7}{|l|}{ Lama Berhenti Merokok } \\
\hline$<4$ tahun & 4 & 100 & 0 & 0 & 4 & \multirow[t]{2}{*}{0,32} \\
\hline$\geq 4$ tahun & 13 & 72,2 & 5 & 27,8 & 18 & \\
\hline Perokok Pasif & & & & & & 0,01 \\
\hline Ya & 44 & 71 & 18 & 29 & 62 & RP : \\
\hline Tidak & 13 & 44,8 & 16 & 55,2 & 29 & 1,58 \\
\hline \multicolumn{7}{|l|}{ Kebiasaan Olahraga } \\
\hline Ya & 23 & 65,7 & 12 & 34,3 & 35 & \multirow[t]{2}{*}{0,79} \\
\hline Tidak & 34 & 60,7 & 22 & 39,3 & 56 & \\
\hline \multicolumn{7}{|l|}{ Frekuensi Olahraga Per Minggu } \\
\hline$<3$ kali & 17 & 68 & 8 & 32 & 25 & \multirow[t]{2}{*}{0,47} \\
\hline$\geq 3$ kali & 6 & 60 & 4 & 40 & 10 & \\
\hline \multicolumn{7}{|l|}{ Lama Olahraga } \\
\hline$\leq 30$ menit & 15 & 71,4 & 6 & 28,6 & 21 & \multirow[t]{2}{*}{0,3} \\
\hline$>30$ menit & 8 & 57,1 & 6 & 42,9 & 14 & \\
\hline \multicolumn{7}{|l|}{ Tingkat Stres } \\
\hline Berat & 8 & 100 & 0 & 0 & 8 & \multirow{4}{*}{0,06} \\
\hline Sedang & 23 & 62,2 & 14 & 37,8 & 37 & \\
\hline Ringan & 12 & 48 & 13 & 52 & 25 & \\
\hline Normal & 14 & 66,7 & 7 & 33,3 & 21 & \\
\hline
\end{tabular}

jumlah rokok yang dihisap satu hari, jenis rokok yang dihisap, dan lama berhenti merokok didapatkan hasil tidak bermakna. Hasil analisis ini sama dengan penelitian yang dilakukan Kasmar (2011), dimana hasil analisis pada kebiasaan merokok menunjukkan hasil bahwa besar risiko kebiasaan merokok terhadap kejadian PJK tidak bermakna. Selain penelitian tersebut, hasil ini juga serupa dengan penelitian Setiani (2009), yaitu besar risiko kebiasaan merokok terhadap kejadian PJK tidak bermakna. Hasil penelitian berbeda dengan hasil penelitian yang dilakukan oleh Sudayasa (2014) yang menunjukkan adanya hubungan yang signifikan antara merokok dengan kejadian PJK. Perbedaan hasil tersebut bisa disebabkan oleh adanya bias seleksi, dan bias informasi dalam penelitian. Selain itu perbedaan metode penelitian juga bisa menyebabkan perbedaan hasil penelitian. Metode case control banyak digunakan oleh penelitian lain, sedangkan metode yang digunakan dalam penelitian ini 
adalah metode cross sectional. Perbedaan dalam hal karakteristik masyarakat juga bisa menjadi perbedaan hasil penelitian. Masyarakat dalam penelitian ini dan masyarakat dalam penelitian lain bisa berbeda dalam karakteristik dalam kehidupan sehari-hari. Adanya faktor risiko lain yang lebih berkontribusi pada kejadian PJK juga bisa menyebabkan adanya perbedaan dalam hasil penelitian seperti penyakit diabetes mellitus, hipertensi, obesitas, dan faktor genetik yang tidak diteliti.

Merokok adalah salah satu faktor risiko utama kejadian penyakit jantung dan mempunyai hubungan kuat dengan terjadinya PJK (Supriyono, 2008). Sekitar 24\% dari jumlah kematian karena PJK terjadi pada laki-laki dan $11 \%$ pada perempuan (Sudayasa et al., 2014). Kebiasaan merokok telah dibuktikan sebagai penyebab meningkatnya morbiditas PJK serta mortalitas akibat PJK (Supriyono, 2008). Kebiasaan merokok adalah salah satu faktor risiko PJK yang dapat dikendalikan karena risiko kebiasaan merokok dapat dikendalikan melalui perubahan perilaku kebiasaan merokok. Menurut WHO, Indonesia menjadi salah satu dari lima negara dengan penduduk perokok terbanyak di dunia (Afriyanti et al., 2015). Merokok merupakan kebiasaan buruk yang cukup membudaya sejak lama di Indonesia. Beberapa tahun terakhir jumlah orang yang memiliki kebiasaan merokok terus meningkat, baik dari segi usia ataupun segi jenis kelamin. Banyak anak usia sekolah yang sudah merokok baik itu SD, SMP, atau SMA. Selain itu saat ini perokok perempuan sudah sering dijumpai dalam masyarakat. Menurut teori, perokok berisiko dua kali lebih besar menderita PJK daripada orang yang tidak merokok (Yuliani et al., 2014). Rokok dapat menyebabkan aterosklerosis yang merupakan awal PJK melalui peningkatan tekanan darah dan denyut jantung, penurunan aliran oksigen menuju jantung, dan peningkatan oksidasi LDL atau disebut lemak jahat sehingga kadar HDL yang disebut lemak baik akan menurun. Rokok dapat menghasilkan polusi partikel padat dan gas dalam udara. Lebih dari 400 jenis bahan kimia beracun dihasilkan dari pembakaran rokok, dan $10 \%$ diantaranya dapat memicu pertumbuhan sel kanker. Zat hasil pembakaran rokok yang dapat membahayakan kesehatan orang sekitar perokok aktif adalah tar, nikotin, karbon monoksida, benzopirin, dan nitrogen sianida. Karbon monoksida atau CO yang terdapat dalam asap rokok dapat mengikat hemoglobin sehingga aliran oksigen ke tubuh berkurang. Pada perokok, risiko PJK lebih besar 2 hingga 4 kali dibandingkan dengan orang yang tidak merokok (Laksmi, 2011). Selain CO dan nikotin, zat dalam rokok yang tak kalah berbahaya adalah tar yang bersifat karsinogenik. Semakin muda usia seseorang untuk mulai merokok, maka semakin lama seseorang tersebut terpapar asap rokok dan zat-zat berbahaya lain yang terdapat dalam rokok. Bila proses tersebut berlangsung lama dan terus menerus, maka akan semakin banyak racun yang menumpuk di tubuh. Salah satu kandungan dalam rokok yaitu nikotin. Nikotin jika beredar dalam tubuh dapat merangsang ekskresi hormon adrenalin yang menimbulkan peningkatan denyut jantung serta tekanan darah serta mengubah metabolisme lemak sehingga kadar LDL meningkat dan kadar HDL menurun. Jika hal ini terus terjadi, maka LDL yang terdapat dalam darah akan mengendap dalam pembuluh darah dan terbentuk plak atau trombus. Jika plak tersebut berjumlah banyak, maka terjadilah aterosklerosis. Nikotin dapat mengakibatkan kerusakan dinding pembuluh darah dan menyebabkan darah mudah menggumpal sehingga memungkinkan terjadinya peningkatan denyut jantung dan tekanan darah (Yuliani et al., 2014). Orang yang memiliki kebiasaan merokok lebih dari 10 tahun bisa terserang PJK (Setiani, 2008). Besar risiko kejadian PJK akibat merokok berkaitan dengan dosis atau jumlah rokok yang dikonsumsi. Perokok yang menghirup lebih dari 20 batang rokok sehari berisiko 2 hingga 3 kali lebih besar daripada orang yang tidak merokok untuk mengalami kejadian PJK (Supriyono, 2008). Jenis rokok yang banyak beredar di masyarakat adalah jenis rokok filter. Didalam rokok filter terdapat filter atau gabus yang dapat menyaring asap rokok yang masuk ke dalam tubuh sehingga jumlah nikotin yang masuk ke dalam tubuh tidak terlalu banyak. 
Konsentrasi nikotin yang terkandung dalam rokok non filter lebih besar karena dalam rokok non filter tidak terdapat filter (Setyanda et al., 2015). Tetapi memakai jenis rokok filter ataupun non filter tetap memiliki dampak buruk bagi tubuh dan bisa menyebabkan PJK. Responden yang pernah memiliki kebiasaan merokok dulunya memang memiliki kebiasaan merokok, tetapi karena alasan tertentu, mereka berhenti merokok. Sebagian besar responden yang pernah merokok telah berhenti merokok $\geq 4$ tahun. Risiko terjadinya PJK karena merokok berkurang sekitar 50\% setelah satu tahun berhenti merokok. Risiko menderita PJK berkurang lagi menjadi normal jika berhenti merokok 4 tahun (Supriyono, 2008). Setelah dua tahun, risiko serangan jantung orang yang berhenti merokok mendekati risiko yang dimiliki oleh orang yang tidak merokok (Kasmar, 2011).

Perokok dapat dibagi menjadi dua berdasarkan cara bahan kimia masuk dalam tubuh, yaitu perokok aktif dan perokok pasif. Perokok aktif yaitu orang yang merokok dan langsung menghisap rokok. Sedangkan perokok pasif yaitu orang yang tidak merokok tetapi menghirup asap rokok dari perokok di sekitarnya. Sebagian besar responden merupakan perokok pasif yaitu orang yang tidak merokok tetapi tinggal atau bekerja bersama dengan perokok sehingga terpapar asap rokok. Hasil penelitian menunjukkan adanya hubungan yang bermakna antara status perokok pasif dengan kejadian PJK pada usia produktif. Angka rasio prevalens sebesar 1,58 menunjukkan bahwa perokok pasif memiliki risiko 1,58 kali menderita PJK daripada bukan perokok pasif. Risiko yang dimiliki perokok pasif meningkat hingga $30 \%$ daripada orang yang bukan perokok pasif (Supriyono, 2008). Asap yang dihasilkan oleh perokok aktif dapat dibedakan menjadi asap utama (main stream smoke), dan asap samping (side stream smoke). Asap utama adalah asap yang dihirup langsung oleh perokok yang berasal dari pembakaran tembakau. Sedangkan asap samping merupakan asap hasil pembakaran tembakau yang telah dihirup oleh perokok aktif lalu tersebar ke udara bebas sehingga kemungkinan dapat dihirup oleh orang lain yang ada di sekitar perokok aktif. Dampak rokok tidak hanya pada perokok aktif, melainkan pada perokok pasif juga, karena asap rokok yang dikeluarkan oleh perokok mengandung karbon monoksida lima kali lebih banyak, dan mengandung tar dan nikotin empat kali lipat lebih besar. Selain menyebabkan PJK, kebiasaan merokok juga merupakan faktor risiko berbagai penyakit lainnya seperti diabetes mellitus, hipertensi, dan kanker. Penelitian yang dilakukan Takeshi Hirayama pada tahun 1981 menunjukkan hasil bahwa wanita Jepang yang menikah dengan seorang peokok menderita kanker paru-paru. Penelitian ini diperluas ke berbagai daerah dan menunjukkan hasil yang sama. Lebih dari satu penelitian acak telah dilakukan pada program pencegahan primer dan menunjukkan penurunan kejadian penyakit jantung dan pembuluh darah sebanyak $7-47 \%$ pada golongan yang mampu berhenti merokok daripada yang tidak berhenti merokok. Berdasarkan hal tersebut dapat diketahui bahwa berhenti merokok merupakan faktor pencegahan PJK yang penting (Supriyono, 2008). Banyak orang mengetahui bahwa rokok banyak mengandung racun dan dapat menyebabkan gangguan kesehatan, khususnya orang yang setiap harinya berhubungan dengan media massa, maupun media elektronik. Sudah banyak promosi kesehatan yang memuat bahaya rokok dan dampak kesehatan yang bisa ditimbulkan. Namun kenikmatan merokok merupakan hal yang membuat masyarakat lupa akan dampak rokok. Hal ini menyebabkan perokok menyepelekan risiko kesehatan penggunaan rokok terhadap diri mereka sendiri maupun orang-orang disekitarnya.

Hasil penelitian menunjukkan hubungan antara faktor risiko kebiasaan olahraga yang terdiri dari kebiasaan olahraga, frekuensi olahraga per minggu, dan lama olahraga menunjukkan hasil tidak bermakna . Hasil penelitian menunjukkan sebagian besar responden tidak memiliki kebiasaan olahraga. Penelitian ini serupa dengan penelitian Supriyono (2008), yang menyebutkan bahwa tidak ada hubungan yang signifikan antara aktifitas fisik dengan PJK, dan juga aktivitas fisik bukanlah faktor risiko untuk kejadian PJK pada usia $\leq 45$ 
tahun. Hasil yang berbeda ditunjukkan oleh penelitian oleh Tsani (2013), yang didapatkan hasil adanya hubungan yang bermakna antara kebiasaan olahraga dengan kejadian PJK. Responden yang tidak memiliki kebiasaan olahraga mempunyai risiko 4,889 kali terkena PJK dibandingkan responden yang memiliki kebiasaan olahraga (Tsani, 2013). Perbedaan hasil penelitian bisa disebabkan karena adanya perbedaan metode penelitian, tempat penelitian, dan karakteristik masyarakat, serta adanya variabel penelitian lain yang berpengaruh pada kejadian PJK yang tidak diteliti.

Olahraga dapat berperan sebagai faktor pelindung, faktor pencegah maupun faktor protektif terhadap berbagai penyakit seperti hipertensi, obesitas, osteoporosis, diabetes mellitus, PJK, dan stroke (Bustan, 2007). Aktifitas fisik atau olahraga ada hubungannya dengan penyakit kardiovaskular., dimana orang yang aktif memiliki risiko lebih kecil menderita PJK daripada mereka yang tidak aktif (Febriani, 2011). Aktivitas fisik atau olahraga dapat bermanfaat dalam kesehatan kardiovaskular. Seperti contohnya mengendalikan tekanan darah, mengontrol berat badan, dan menurunkan risiko penyakit jantung lainnya. Dengan berolahraga teratur dapat bermanfaat menurunkan faktor risiko kenaikan HDL, menurunkan LDL dan menurunkan berat badan (Supriyono, 2008). Hasil penelitian menunjukkan bahwa sebagian besar responden berolahraga kurang dari 3 kali dalam satu minggu. Tingkat keseringan olahraga dapat mempengaruhi tingkat keefektifan aktivitas fisik. Disarankan untuk berolahraga sekitar sampai 3 kali dalam satu minggu dengan lama olahraga 20 menit. Olahraga yang dilakukan tidak perlu olahraga yang memerlukan berbagai alat berat. Olahraga yang dilakukan cukup olahraga atau gerakan tubuh yang menggerakkan otot besar secara berirama dan berulang selama satu periode waktu. Olahraga jenis seperti ini merupakan olahraga yang terbaik bagi jantung karena dapat menyetabilkan denyut jantung. Olahraga yang dimaksud adalah jalan kaki dengan kecepatan tidak terlalu cepat, jogging, lari, bersepeda, dan juga berenang. Jenis olahraga ini tidak perlu dilakukan terlalu sering misalnya setiap hari karena dapat menyebabkan otot kurang istirahat. Tetapi juga tidak boleh dilakukan terlalu jarang karena hasilnya akan tidak efektif. Perkembangan jaman dewasa ini telah menciptakan banyak teknologi yang bisa bermanfaat dalam kehidupan manusia. Salah satu contohnya adalah teknologi dalam bidang transportasi. Perkembangan transportasi saat ini sudah membawa banyak manfaat untuk menunjang aktivitas manusia. Manusia sudah tidak perlu lagi mengeluarkan banyak tenaga untuk berpindah tempat dan bepergian karena sudah adanya alat transportasi. Tentunya hal ini membawa akibat atau efek yang kurang menguntungkan untuk tubuh manusia. Kemudahan menggunakan alat transportasi menyebabkan manusia akan semakin sering menggunakan alat transportasi tersebut sehingga tubuh manusia mengalami fase tidak aktif karena manusia lebih memilih untuk menggunakan alat transportasi. Selain alat transportasi, teknologi yang bisa membawa dampak pada kesehatan manusia adalah adanya lift dalam bangunan. Manusia akan lebih memilih untuk menggunakan lift daripada menggunakan tangga. Padahal menggunakan tangga akan lebih sehat. Bustan (2007), menyatakan bahwa olahraga terbukti jelas memberi peranan pencegahan terhadap PJK. Pada kehidupan sehari-hari sangat perlu untuk melakukan olahraga karena dalam olahraga banyak membawa manfaat diantaranya adalah meningkatkan aliran darah dari organ yang kurang aktif ke organ yang aktif, mengendalikan tekanan darah, menurunkan kadar kolesterol darah, mengurangi risiko obesitas, mengurangi stres dan menjaga berat badan tetap ideal. Olahraga atau aktifitas fisik merupakan akitivitas yang dilakukan oleh tubuh dan bermanfaat dalam menjaga kesehatan dan daya tahan jantung, paru-paru, otot serta sendi. Olahraga teratur dapat memberi dampak yang bermanfaat besar bagi tubuh (Salim \& Nurrohmah, 2013). Apabila kebiasaan olahraga dilakukan pada umur sebelum 60 tahun maka dapat menurunkan risiko terkena PJK. Sedangkan bila dilakukan pada umur diatas 60 tahun tidak mengurangi risiko seseorang terkena PJK karena keadaan pembuluh darah yang tidak 
sama lagi dan banyak mengalami kelemahan (Febriani, 2011).

Hasil penelitian menunjukkan bahwa $40,7 \%$ responden mengalami tingkat stress sedang. Hubungan tingkat stres dengan kejadian PJK pada penelitian ini dinyatakan tidak bermakna karena $\mathrm{p}$ value $>\alpha(0,05)$. Hasil penelitian ini berbeda dengan hasil penelitian Sudayana (2014) yang menunjukkan adanya hubungan yang bermakna antara tingkat stres dengan kejadian PJK. Risiko menderita PJK pada orang yang mengalami stress lebih besar 6,25 kali daripada risiko yang dimiliki oleh orang yang bukan perokok (Sudayasa et al., 2014). Perbedaan hasil penelitian tersebut didasarkan pada perbedaan kuisioner penilaian stres yang digunakan. Kuisioner DASS 42 (Depression Anxiety Stress Scale) bertujuan untuk mengetahui tingkat stres yang dialami seseorang dalam kehidupan sehari-hari. Pertanyaan dalam kuisioner DASS 42 dibagi menjadi 3 bagian, yaitu pertanyaan tentang stres, pertanyaan tentang tingkat ansietas atau kecemasan, dan pertanyaan tentang tingkat depresi. Stres merupakan salah satu faktor risiko PJK yang dapat dikendalikan dengan cara mengendalikan stres. Sumber stres atau bisa disebut stressor berasal dari dari dalam diri individu seperti perasaan negatif, frustasi, cemas, marah, kuatir berlebih, sedih, dan rasa rendah diri. Selain dalam diri individu, stres juga bisa berasal dari luar diri individu seperti suara bising, polusi, suhu yang tinggi, makanan, dan aktivitas fisik. Gejala fisiologis stres diantaranya adalah meningkatnya denyut jantung, meningkatnya tekanan darah, gangguan pencernaan, dan meningkatnya sekresi hormon stres yaitu hormon adrenalin dan noradrenalin. Jika hal ini terjadi, maka hormon adrenalin yang keluar akan menganggu metabolism lemak sehingga kadar LDL akan tinggi. Selain menaikkan kadar LDL, hormon adrenalin juga akan meningkatkan tekanan darah. Selain itu respon menghadapi stres yang bisa dialami pada individu dapat diamati dari fisik maupun psikologisnya. Secara umum respon stres lebih dihubungkan dengan emosi, seperti mudah marah, sedih, mudah merasa tersinggung, mudah kecewa, dan gelisah. Data epidemiologis menunjukkan bahwa stres kronis dapat meningkatkan risiko PJK. Selain itu, stres emosional jangka pendek dapat bertindak sebagai pemicu kejadian penyakit jantung antara individu dengan terjadinya aterosklerosis. Faktor yang dapat mempengaruhi tinggi rendahnya tingkat stres salah satunya adalah dukungan sosial dari keluarga dan orang sekitar. Dengan adanya dukungan sosial, maka hal ini dapat membuat seseorang yang merasa stres mengubah perilakunya dalam menghadapi sumber stres supaya lebih tenang dan dengan pemikiran yang baik. Stres dapat dicegah dengan cara mengubah pandangan atau reaksi pada suatu keadaan. Mencegah stres dapat dilakukan dengan berbagai cara, diantaranya adalah olahraga secara teratur, istirahat cukup, dan melakukan gerakan relaksasi (Muawanah, 2012).

\section{SIMPULAN}

Hubungan antara status perokok pasif dan kejadian PJK pada usia produktif bermakna. Nilai RP (Rasio Prevalensi) sebesar 1,58 menunjukkan bahwa orang yang merupakan perokok pasif memiliki risiko 1,58 kali menderita PJK daripada orang yang bukan perokok pasif. Sedangkan variabel lain yaitu kebiasaan merokok, umur mulai merokok, jumlah rokok yang dihisap per hari, jenis rokok yang dihisap, dan lama berhenti merokok tidak bermakna. Hubungan antara faktor risiko kebiasaan olahraga yang terdiri dari kebiasaan olahraga, frekuensi olahraga per minggu, dan lama olahraga dengan kejadian PJK pada usia produktif tidak bermakna. Hubungan antara tingkat stres dengan kejadian PJK pada usia produktif tidak bermakna. Hubungan yang tidak bermakna menunjukkan bahwa hasil penelitian ini hanya bisa diterapkan di tempat penelitian yaitu RSU Haji Surabaya, dan tidak bisa digeneralisasikan ke populasi umum.

\section{SARAN}

Kebiasaan merokok perlu dihindari karena terbukti jelas memberi peranan yang buruk bagi kesehatan. Orang yang terlanjur memiliki kebiasaan merokok disarankan 
untuk berhenti merokok, dan sebisa mungkin tidak merokok di tempat yang terdapat banyak orang, seperti di dalam rumah, kantor, kendaraan umum, atau fasilitas umum lainnya. Perokok pasif disarankan supaya sebisa mungkin menghindari asap rokok yang dikeluarkan oleh perokok aktif bisa dengan menggunakan masker ataupun menghindari orang yang sedang merokok. Kegiatan olahraga atau aktivitas fisik perlu ditingkatkan. Aktivitas fisik yang dilakukan sebaiknya teratur 2-3 kali per minggu dengan durasi kurang lebih 20 menit. Stres juga perlu dihindari supaya tidak terjadi penyakit-penyakit akibat stres. Langkah atau cara yang bisa dilakukan untuk mengendalikan stres diantaranya adalah olahraga, melakukan gerakan relaksasi, dan beristirahat cukup. Selain itu health education atau pendidikan kesehatan terkait faktor risiko dan tanda serta gejala PJK perlu diberikan pada masyarakat untuk adanya upaya deteksi dini terhadap PJK sehingga perawatan yang dilakukan bisa diberikan secepat mungkin dan menghindari komplikasi yang dapat berakibat fatal. Untuk penelitian selanjutnya, supaya lebih memperhatikan pemilihan responden, lebih memperhatikan pemilihan pertanyaan, dan juga pemilihan variabel penelitian lain yang lebih berpengaruh pada kejadian PJK.

\section{DAFTAR PUSTAKA}

Afriyanti, R., Pangemanan, J., Palar, S. 2015. Hubungan Antara Perilaku Merokok Dengan Kejadian PJK. Jurnal e-Clinic (eCl), 3, pp.98-102.

American Heart Association. 2015. American Heart Association. [Online] Available at: HYPERLINK "www. heart.org/HEARTORG/Conditions/ More/MyHeartandStrokeNews/ Coronary-Artery-Disease---CoronaryHeart-Disease_UCM_436416_Article. jsp" $\backslash 1$ ".VmEAKKnYrLIV" www.heart. org/HEARTORG/Conditions/More/ MyHeartandStrokeNews/CoronaryArtery-Disease---Coronary-HeartDisease_UCM_436416_Article.jsp\#. VmEAKnYrLIV [Accessed 4 December 2015].
Bustan, M.N. 2007. Epidemiologi Penyakit Tidak Menular. 2nd ed. Jakarta: Rineka Cipta.

Febriani, F. 2011. Risiko Kebiasaan Olahraga (Training) Terhadap Kejadian PJK Pada Penderita Yang Berobat di RSU Haji Surabaya. Skripsi. Universitas Airlangga.

Herman, S.I., Syukri, M., Efrida, 2015. Hubungan Faktor Risiko Yang Dapat Dimodifikasi Dengan Kejadian PJK di RS dr.M.Djamil Padang. Jurnal Kesehatan Andalas, 4(2), pp.369-75.

Kasmar, N. 2011. Risiko Pola Makan Dan Kebiasaan Merokok Terhadap Kejadian PJK (Studi di RSU Haji Surabaya). Skripsi. Universitas Airlangga.

Kementrian Kesehatan RI. 2014. Situasi Kesehatan Jantung. Jakarta: Pusat Data dan Informasi Kementrian Kesehatan RI.

Laksmi, A.N. 2011. Perilaku Merokok dan Kesegaran Jasmani (VO2 MAX) Pada Atlet Sepakbola U-21 Kabupaten Sidoarjo. Skripsi. Universitas Airlangga.

Muawanah. 2012. Hubungan Tingkat Pengetahuan Tentang Manajemen Stres Terhadap Tingkat Kekambuhan Pada Penderita Hipertensi Di Panti Wreda Dharma Bhakti: Surakarta.

Ramandika, E.A. 2012. Hubungan Faktor Risiko Mayor PJK Dengan Skor Pembuluh Darah Koroner Dari Hasil Angiografi Koroner di RSUP dr.Kariadi Semarang. Jurnal Media Medika Muda.

Salim, A.Y., Nurrohmah, A. 2013. Hubungan Olahraga Dengan Kejadian Penyakit Jantung Korober di RSUD dr.Moewardi. GASTER, 10, pp.48-56.

Setiani, R. 2008. Faktor Risiko Yang Berhubungan Dengan Kejadian PJK (PJK) Pada Kelompok Usia Produktif Skripsi. Universitas Airlangga.

Setyanda, Y.O.G., Sulastri, D, Lestari, Y. 2015. Hubungan Merokok Dengan Kejadian Hipertensi Pada Laki-Laki Usia 35-65 Tahun di Kota Padang. Jurnal Kesehatan Andalas, 4(2), pp.434-40.

Sudayasa, I.P., Subijakto, S., Sahrul, W.O.A., 2014. Analisis Faktor Risiko Merokok, Stres, dan Riwayat Keluarga Yang Berhubungan Dengan Kejadian PJK. 
Jurnal Fakultas Kedokteran UHO, pp.48-56.

Supriyono, M. 2008. Faktor-Faktor Risiko yang Berpengaruh Terhadap Kejadian PJK Pada Kelompok Usia Tesis. Universitas Diponegoro.

Tsani, F.R. 2013. hubungan Antara Faktor Lingkungan dan Perilaku Dengan
Kejadian PJK (Studi Kasus di Rumah Sakit X Kota Semarang). Unnes Journal of Public Health, 3, pp.1-9.

Yuliani, F., Oenzil, F., Iryani, D. 2014. Hubungan Berbagai Faktor Risiko Terhadap Kejadian PJK Pada Penderita Diabetes Mellitus Tipe 2. Jurnal Kesehatan Andalas, 3(1), pp.37-40. 